\section{Re: Academic integrity and plagiarism}

Sir,

We read the publication on Academic integrity and plagiarism' with a great interest. ${ }^{[1]}$ Kadam noted that 'Institutions and authors should have an easy access to good screening software for manuscripts. The responsibility of submitting an unblemished manuscript rests with the authors, researchers and guides. Senior authors cannot absolve themselves from the responsibilities. ${ }^{[1]}$ We agree with this statement. Indeed, the responsibility of the authors regarding the originality of the manuscript is very important. The use of screening software for plagiarism might be helpful, but the real reason remains an unethical and dishonest plagiarist. The software can play no role if there is no ethical mind of the practitioner. In many developing countries, the senior authors or administrators might be the plagiarists, but they usually get no punishment despite the plagiarisms are identified. ${ }^{[2]}$ The neglected unethical 
problem by the institute is common, and there should be the role of the academic society against the unwanted plagiarism behaviour. Prevention of plagiarism should start with early education of newcomers and medical students. It is important to demonstrate a "bad case" to the newcomers and they should be trained to recognize such problems so that, they refrain from such act in future.

\section{Financial support and sponsorship}

Nil.

\section{Conflicts of interest}

There are no conflicts of interest.

Beuy Joob, Viroj Wiwanitkit ${ }^{1}$

Sanitation 1 Medical Academic Center, Bangkok, Thailand, ${ }^{1}$ Department of Community Medicine, Dr. D. Y. Patil

University, Pune, Maharashtra, India

Address for correspondence: Dr. Beuy Joob, Sanitation 1 Medical Academic Center, Bangkok, Thailand.

E-mail: beuyjoob@hotmail.com

\section{REFERENCES}

1. Kadam D. Academic integrity and plagiarism: The new regulations in India. Indian J Plast Surg 2018;51:109-10.

2. Wiwanitkit V. Plagiarism, management, journal retraction and response by author's institute. Saudi J Anaesth 2013;7:223.

This is an open access journal, and articles are distributed under the terms of the Creative Commons Attribution-NonCommercial-ShareAlike 4.0 License, which allows others to remix, tweak, and build upon the work non-commercially, as long as appropriate credit is given and the new creations are licensed under the identical terms.

\begin{tabular}{|l|l|}
\hline \multicolumn{2}{|c|}{ Access this article online } \\
\hline Quick Response Code: & Website: \\
\hline
\end{tabular}

How to cite this article: Joob B, Wiwanitkit $\mathrm{V}$. Re: Academic integrity and plagiarism. Indian J Plast Surg 2018;51:344-5.

$\odot 2019$ Indian Journal of Plastic Surgery | Published by Wolters Kluwer - Medknow 